\title{
APPLICATION OF THE PRECISION LEVELLING METHOD TO EVALUATE THE VERTICAL MOVEMENTS WITHIN EASTERN PART OF THE ELBE FAULT SYSTEM (SW POLAND, WESTERN SUDETES)
}

\author{
Olgierd JAMROZ ${ }^{1)_{*}}$, Janusz BADURA ${ }^{2)}$ and Krzysztof MĄKOLSKI ${ }^{1)}$ \\ 1) Wroclaw University of Environmental and Life Sciences, Institute of Geodesy and Geoinformatics, \\ Grunwaldzka 53, 50-357 Wroctaw, Poland \\ ${ }^{2)}$ Polish Geological Institute, National Research Institute, Lower Silesian Branch in Wrocław, \\ Jaworowa Ave. 19, 53-122 Wroctaw, Poland \\ *Corresponding author's e-mail: olgierd.jamroz@igig.up.wroc.pl
}

\begin{tabular}{l} 
ARTICLE INFO \\
\hline Article history: \\
Received 31 October 2014 \\
Accepted 1 December 2014 \\
Available online 5 December 2014 \\
\hline
\end{tabular}

\section{Keywords:}

Precise levelling

Vertical movements

Elbe Fault System

Nysa Kłodzka Graben

Nysa-Morava Fault Zone

Neotectonics

\begin{abstract}
The eastern part of the Elbe Fault System covers an area of the Bohemian Massif located between the middle Odra faults in the north, and the system jumps to the south of the Elbe edging the Bohemian Cretaceous Basin on the orientation of NW-SE to WNW-ESE. The Sudetic horst is located in the middle part of this area, and within it there are distinguishable, smaller tectonic forms that arise after the Cretaceous-Paleogene inversion. In this part of the Western Sudetes, the Nysa Kłodzka Graben is clearly marked, and surrounding it, horst formations: Bardo Mountains, Złote Mountains, Śnieżnik Massif, Orlickie and Bystrzyckie Mountains. In this part of the Sudetes there are many more complementary faults with directions of NNW-SSE or NNE-SSW.

The lack of correlative deposits makes difficult to identify stages of the Nysa Kłodzka Graben tectonic development. However, it is estimated that since the Miocene until today, displacement between the bottom of the graben, and the surface of the Śnieżnik Massif peak had an amplitude about of 1000-1200 m. On the basis of indirect evidence, it can be assumed that since the late Miocene to the present, the northern border of the graben has increased by about $50 \mathrm{~m}$ and the southern, by about $15 \mathrm{~m}$. Numerous gorges and places of an occurring lattice system of river valleys indicates that this area is still little changed as a result of tectonic movements. Weak seismicity of the area is recorded in the historical documents, and now recorded by the seismic stations. Satellite measurement campaigns (GNSS) conducted in this area during the last 20 years confirm the trend of vertical movement points. They also point to the diversity (velocity and directions) of horizontal displacements (Kapłon et al., 2014). Attempts to determine the scale of the vertical displacements in repeated precision levelling lines confirm the relative displacement occurring between the bottom of the Nysa Kłodzka Graben and its metamorphic frame, and also indicate weak tectonic movements that occur within the graben bottom.
\end{abstract}

\section{INTRODUCTION}

The evaluation of vertical activity areas of the Śnieżnik Massif, Krowiarki, Złote Mountains and Nysa Kłodzka Graben was carried out on the basis of measurements at the I-st and II-nd class state precise levelling lines, located near these areas.

The analysed sequences of precise levelling include the western and eastern borderland of the Sudetes: Złote Mountains (Rychlebské), Laskówka depression, Bardo Mountains, Śnieżnik Massif and Kłodzko Valley (Fig. 1). According to the geological division, physiographic units mentioned above are part of the Western Sudetes. In this part of the Sudetes there are the following tectonic units: granitoid Kłodzko-Złoty Stok Massif, Orlica-Śnieżnik Dome (OSD), Bardo Unit, Kłodzko Metamorphic and Upper Nysa Kłodzka Graben (UNKG) (see Fig. 2). Within OSD there is the distinctive Młynowiec-Stronie Group (Żelaźniewicz et al., 2014). Within UNKG there are several sub-sedimentary basins of varying thickness of Cretaceous sediments changing to 100 to $700 \mathrm{~m}$
(Radwański, 1975; Don, 1996). Badura and Rauch (2014) believe that the current differences in the thickness of the Cretaceous sediments may have a secondary character. They were created as a result of the uneven uplift and erosion that has taken place in this area, mainly during the Miocene and Pliocene. In the Upper Cretaceous the area mentioned above was located on the southern edge of the European platform. After the Cretaceous period, the area of the Sudetes, along with the entire Czech massif, has been unevenly uplifted (Ziegler and Dézes, 2007). The framework of the former Cretaceous basin has been uplifted by about 700 to $1000 \mathrm{~m}$, in relation to the ceiling of the Upper Cretaceous sediments. In the UNKG, there is also marked diversity of the uplifting rate. A number of indirect geomorphological evidence indicates that tectonic movements are still occurring in this area (Pospíšil et al., 2013). They are now more easily identified by geodetic methods than geological methods. 


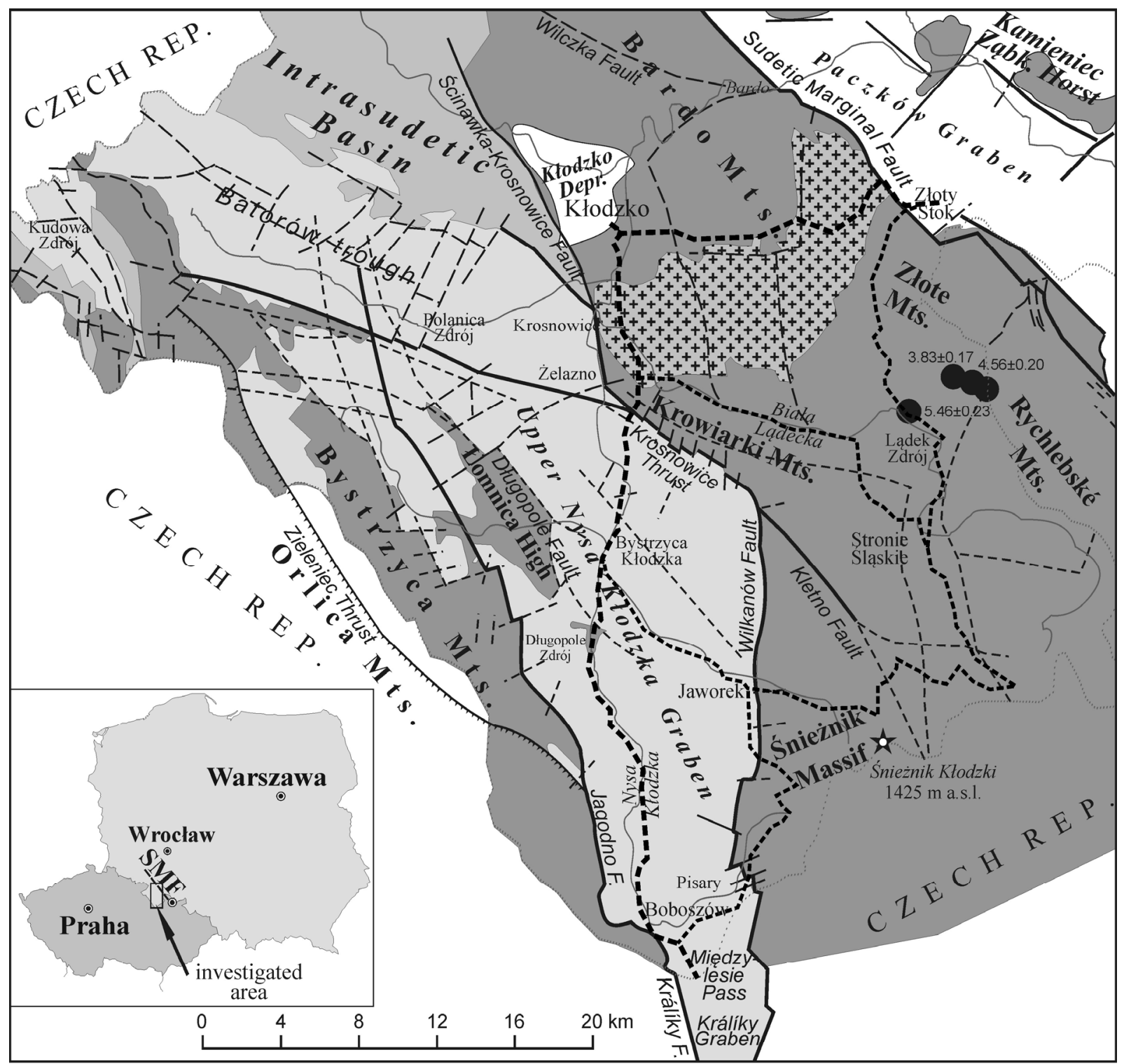

Proterozoic and Palaeozoic crystalline rocks Variscan granitoids

Lower Permian volcanic and clastic deposits Upper Cretaceous marls and clastic deposits

Upper Miocene and Pliocene bazaltoids age determined by the $\mathrm{K}$-Ar metod in $\mathrm{Ma}$ Cenozoic deposits on the Sudetic Foreland and Kłodzko Depression Thrusts active in the Late Neogene and probably in the Pleistocene

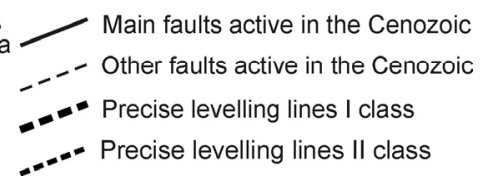

Fig. 1 Precise class I and II levelling lines on the background of the major tectonic units of the Central Sudetes.

\section{METHODS AND RESULTS}

Data have been used from precise measurements of levelling lines in a polygon 156 to assess the vertical crustal movement. These data come from the Central Documentation Centre of Geodesy and Cartography in Warsaw, Poland. Polygon 156 consists of the class I lines: Złoty Stok-Kłodzko and KłodzkoBoboszów; and lines of class II: Złoty Stok-Stronie Śląskie, Żelazno-Stronie Śląskie, Stronie ŚląskieJaworek, Bystrzyca Kłodzka-Jaworek and JaworekBoboszów.
In the first stage, the completeness and consistency of the levelling data was carried out to identify benchmarks in selected lines. With further description, benchmarks that were damaged and impossible to uniquely identify were eliminated. After the selection, data were used from the selected results of the campaigns of years 1953 to 2002 (class I lines) and from 1989 to 2008 (class II lines). To analyse the stability, comparative archival data from the XIX century were used. Theoretical problems related to the choice of common benchmarks for different periods of research are described, among other things, in the 


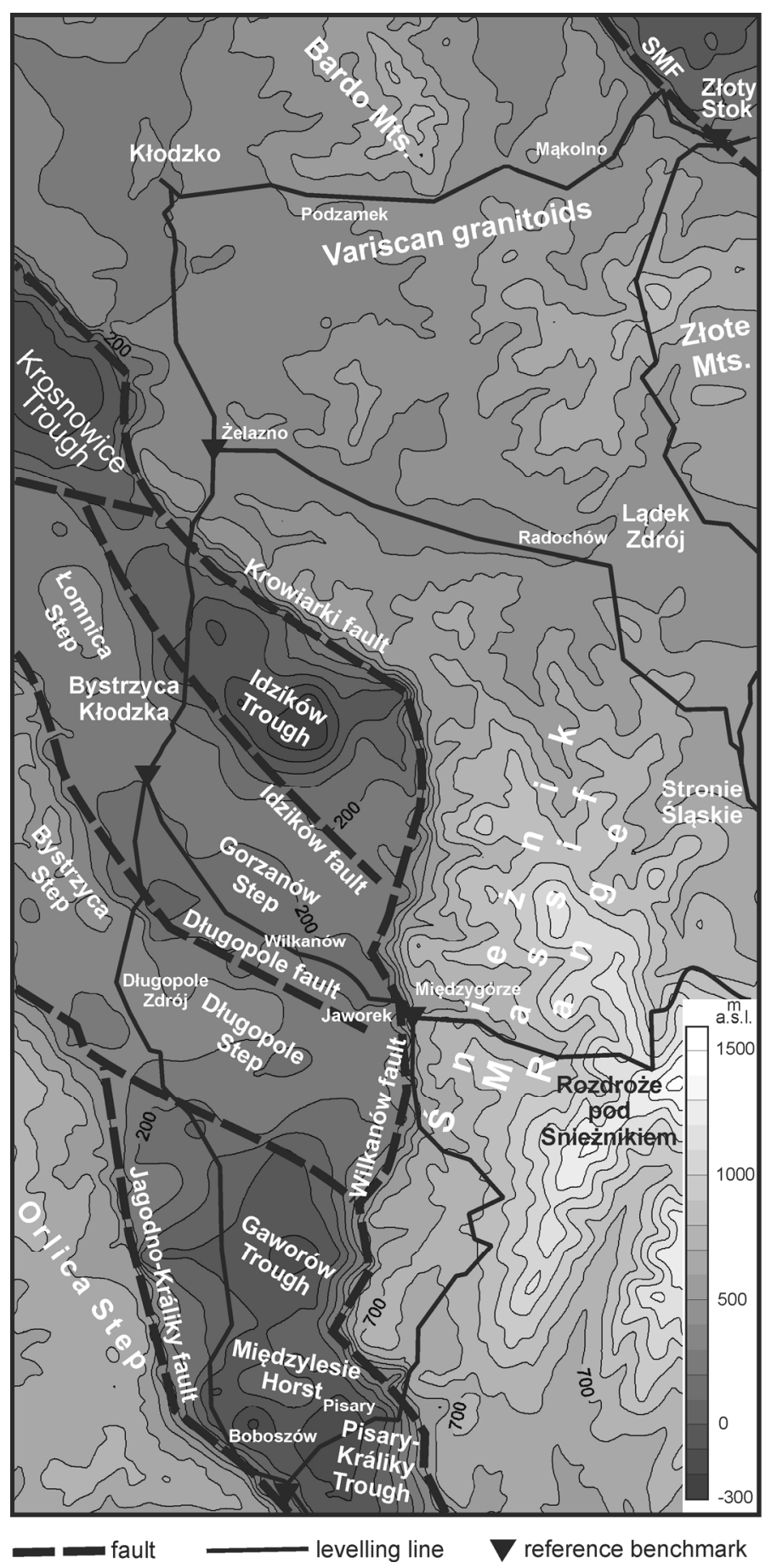

Fig. 2 Geovisualization of the sub-Cretaceous surfaces in the Upper Nysa Kłodzka Graben and main Cenozoic faults.

works of Wyrzykowski (1985, 1988), Kowalczyk (2009) and Kowalczyk at al. (2011).

The analysis led to isolating fixed benchmarks, forming a reference frame. Subsequently, the changes in the benchmarks elevations and the velocity of vertical movement along the levelling lines were calculated. Interpretation of the geometric changes was carried out taking into consideration the geomorphological and geological-tectonic conditions. Selected reference benchmarks were regionally relatively stable in the long term. The benchmark's vertical movement velocities were calculated on the basis of height differences without normal correction. Graphical illustration of the results is shown in Figs. 3-8. 


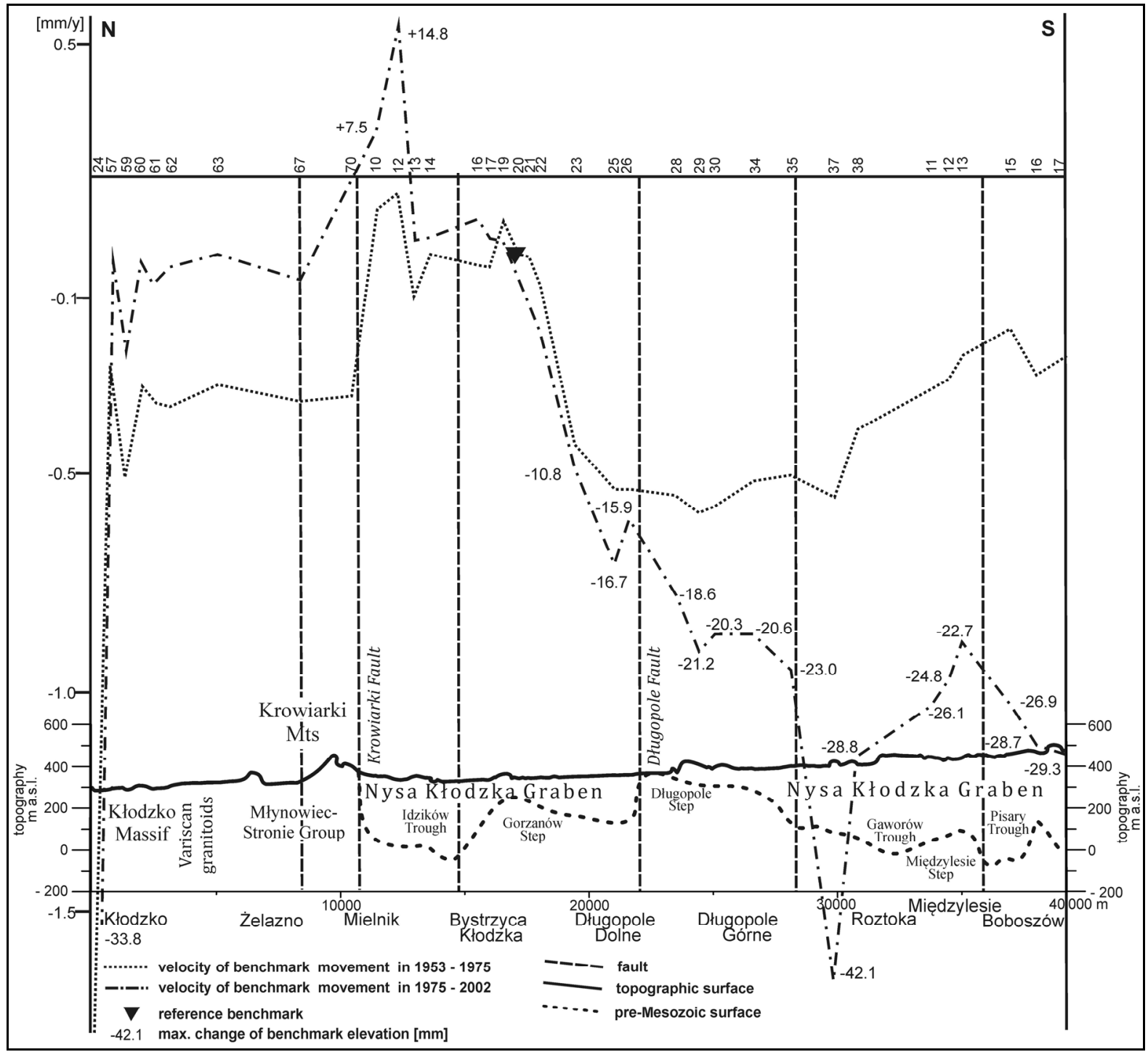

Fig. 3 Velocity of vertical displacements in the line Kłodzko-Boboszów (class I levelling).

Changes in the benchmark elevations and the velocity of these changes for levelling line KłodzkoBoboszów (class I) relate to periods 1953-1975 and 1975-2002. For this line in the region of Kłodzko and Żelazno, there were initially observed signs of subsidence $(-0.2 \mathrm{~mm} /$ year to $-0.5 \mathrm{~mm} /$ year $)$. In the years 1975-2002 the benchmarks show an uplifting tendency (Fig. 3). For most of the benchmarks, the result of these movements is close to 0. Only the benchmark no. 24 in Kłodzko in the years 1953 to 1975 subsided at a velocity of more than $-1.5 \mathrm{~mm} /$ year. In the next period it was slightly uplifted. These movements were associated with suffosion elution of this part of sediments beneath the town hall, where the benchmark is fixed.

In the region of Mielnik, uplifting trends up to $0.5 \mathrm{~mm} /$ year were observed. The visible uplifted zone is associated with the range of Krowiarki Mountains. This area is separated from Nysa Kłodzka Graben by the Krosnowice framework fault from the south. Within Krowiarki there are probably faults associated with the parallel valley also. The lack of outcrops makes it impossible to confirm whether this is a valley with lithological or tectonic origin. A zone with benchmarks indicating the uplift is observed in Bystrzyca Kłodzka, but it has a very gentle character (up to $0.1 \mathrm{~mm} /$ year). Perhaps this is related to the crossing through the measurement line by the latitudinal Kamienna Góra-Gorzanów horst (Badura and Rauch, 2014). In the center of Bystrzyca Kłodzka two benchmarks demonstrate stability. Towards the Długopole levelling line, another fault zone intersects, which is associated with the Długopole tectonic step (op. cit.). To the south of Długopole Zdrój, the subsidence of all benchmarks is clearly indicated. For the years 1953-1975, there are subsidences recorded of $-0.5 \mathrm{~mm} /$ year in the region Długopole and Roztoka to approximately $0.3 \mathrm{~mm} /$ year near Boboszów. In the 


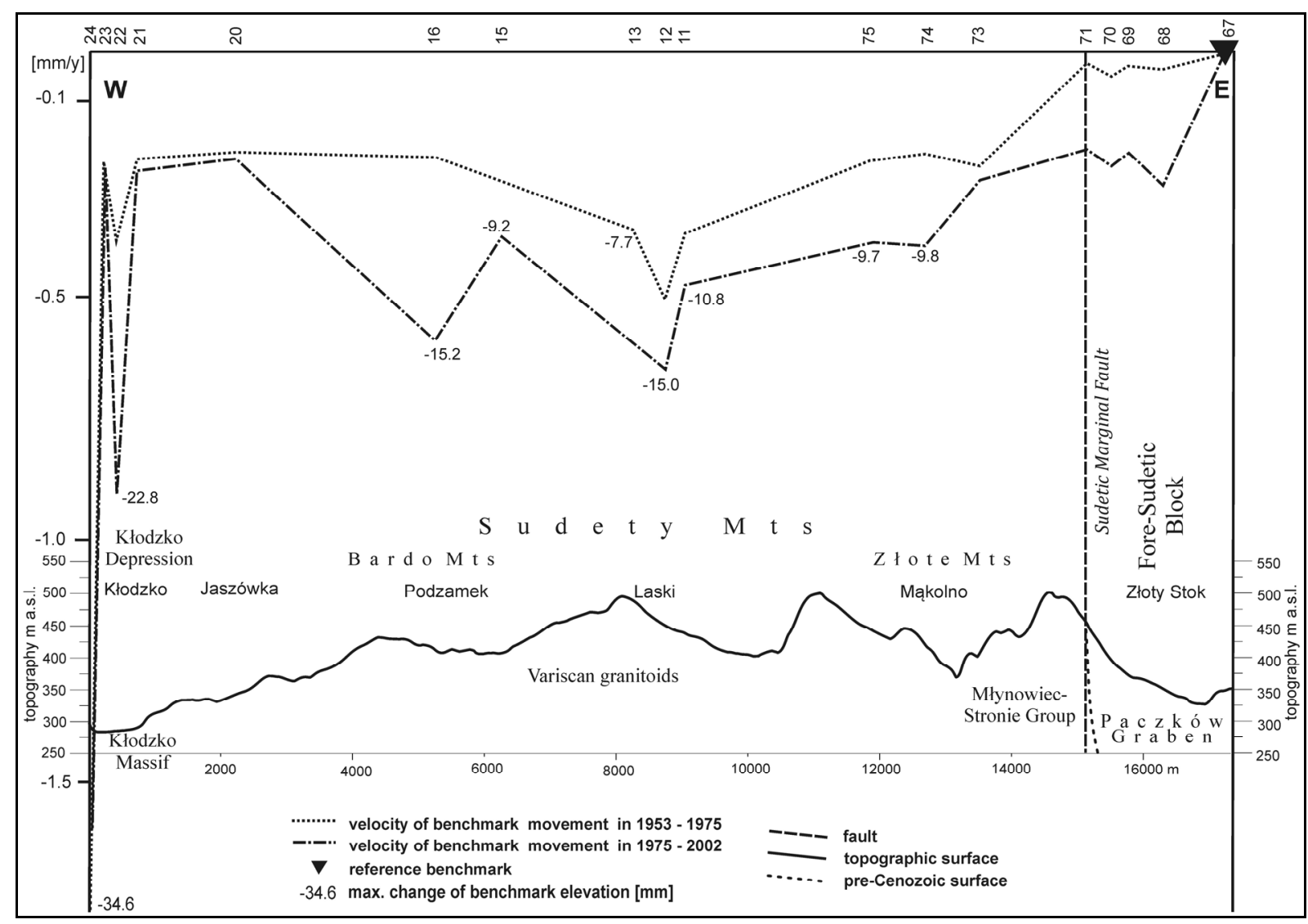

Fig. 4 Velocity of vertical displacements in the line Kłodzko-Złoty Stok (class I levelling).

next study period, these trends significantly deepen, and the maximum change in the benchmarks was detected in the area of Roztoka $(-42.1 \mathrm{~mm})$ and Boboszów $(-29.3 \mathrm{~mm})$. This lowering is related to the deepest part of the Nysa Kłodzka Graben-Pisary Foredeep, continuing until Králíky in the Czech side. The relatively weaker subsidence in the area of Międzylesie is probably related to the occurrence of the Międzylesie horst under Upper Cretaceous rocks.

Class I levelling line Kłodzko-Złoty Stok (Fig. 4) crosses latitudinally the Fore-Sudetic Block with the Paczków Graben, Złote and Bardo Mountains with the Laskówka Depression. In the Złoty Stok, this line crosses the Sudetic Marginal Fault (SMF), which separates Paczków Graben from Sudetes. In the western part of the profile runs the Kłodzko Valley section of the watershed Nysa Kłodzka River in Kłodzko. For the entire line, there is a clear trend of settling the benchmarks. The exception is the previously commented movement of the benchmark in Kłodzko. To the west in the area of Złoty Stok, a group of benchmarks is decreasing from $-0.05 \mathrm{~mm} /$ year in the period $1953-1975$ to $-0.2 \mathrm{~mm} /$ year in $1975-2002$. The movement trend is weaker than in the area of outcrop of Variscan granitoids near Mąkolno, where the amplitude of the changes ranges from $-9.8 \mathrm{~mm}$ to $-16.9 \mathrm{~mm}$ near
Podzamek. The explanation for the declining trend of the Bardo and Złote Mts. in light of previous geological studies is impossible. Geomorphological analysis of the Nysa Kłodzka river terrace position (Przybylski, 1998; Krzyszkowski et al., 2000), the shape of a drainage basin of creeks crossing Sudetes, and triangular facets in morphotectonic Sudetic Marginal Fault suggest lifting movements (Badura et al., 2007; Štěpančíková et al., 2010).

Next, Laski zone limited by tectonic faults, where subsidence velocity slightly exceeds $-0.5 \mathrm{~mm} /$ year in the initial phase of the analysed periods. The recorded maximum subsidence of benchmarks reaches $-15.0 \mathrm{~mm}$. A similar picture is presented in a Podzamek area limited by dislocations, where the calculated subsidence is $-15.2 \mathrm{~mm}$ for the period 1953-2002. Each set of zones is characterised by subsidence velocity variation. The Podzamek zone is separated by another dislocation from the Jaszówka zone where subsidence was approximately $-0.2 \mathrm{~mm} /$ year in the initial period. An analysis of measurement results from the years 1975-2002 can lead to a hypothesis about the stagnation of movements.

In the line Boboszów-Jaworek (class II) a subsidence has occurred (Fig. 5). The rate of subsidence in the period since 1989 comes to 


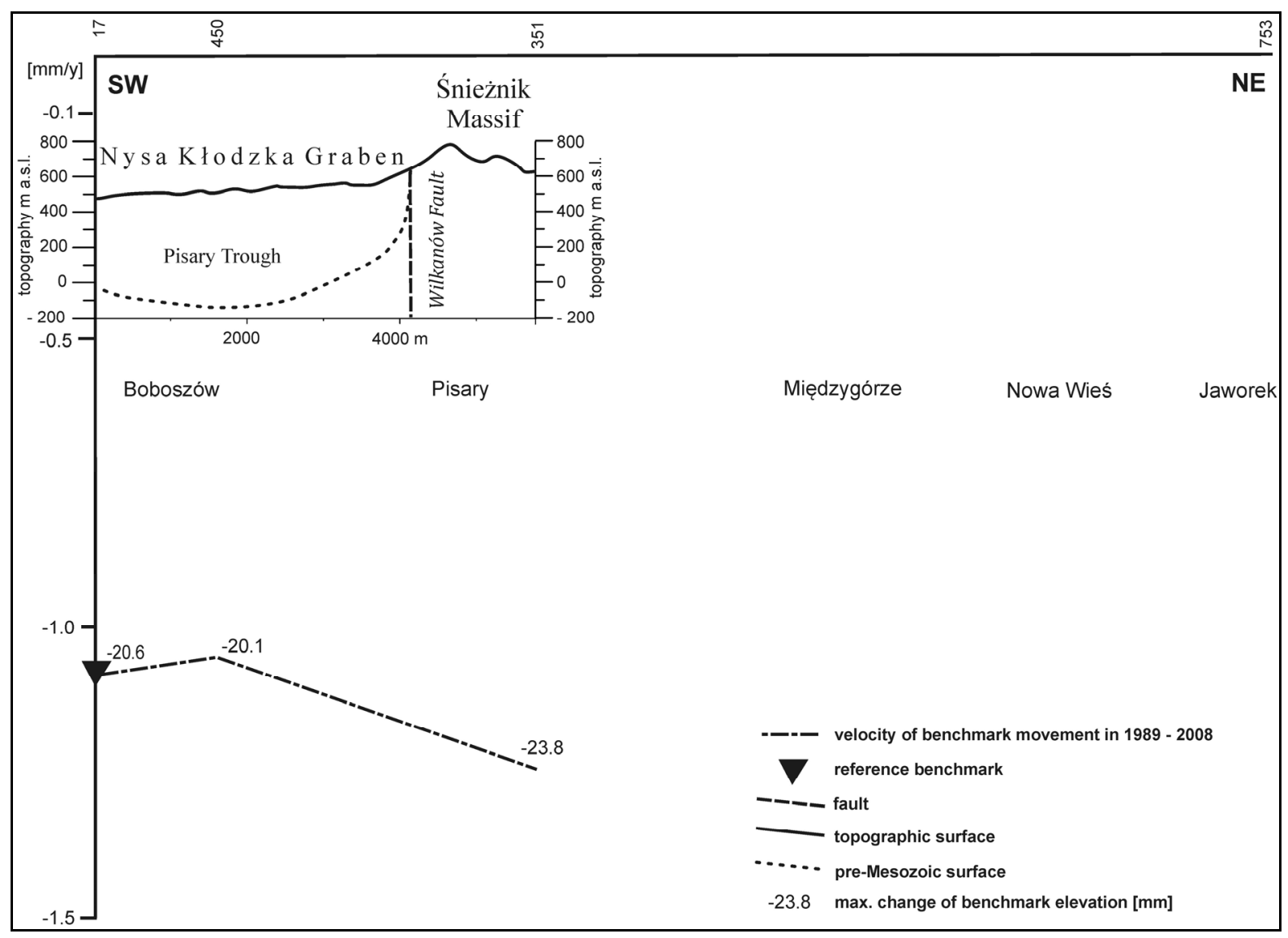

Fig. 5 Velocity of vertical displacements in the line Boboszów-Jaworek (class II levelling).

- $1.2 \mathrm{~mm} / \mathrm{year}$ in the Pisary area. The analysed section is located within the deepest part of the Upper Nysa Kłodzka Graben (Badura and Rauch, 2014).

Measurements of two lines of class II levelling Bystrzyca Kłodzka-Jaworek and Jaworek-Stronie Śląskie - were made during 1989-2008. The 19 year period between measurements, however, allows for the indication of uplifting in the Wilkanów and Międzygórze area, of up to $0.3 \mathrm{~mm} /$ year, and subsidence in excess of $-1.5 \mathrm{~mm} /$ year in the nearby Rozdroże pod Śnieżnikiem, where the amplitude of the benchmark elevation changes reaches $-34.9 \mathrm{~mm}$ (Fig. 6). We consider this benchmark to be uncertain, and we do not associate the observed movement with natural geological processes.

Benchmarks from class II levelling line ŻelaznoStronie Śląskie were uplifted for the period 1989-2008 (Fig. 7). In the Ołdrzychowice area these vertical movements occur at an average rate of 0.4 to $0.5 \mathrm{~mm} /$ year. The greatest severity was observed between Ołdrzychowice and Trzebieszowice (approximately $1.1 \mathrm{~mm} /$ year), where the uplifting amplitude is the largest-almost to $21 \mathrm{~mm}$. Next, in the direction of Stronie Śląskie two benchmarks are noteworthy in the area of Trzebieszowice and Radochów. They have been increasing approximately $15-17 \mathrm{~mm}$, which reflects the rate of deformation of the rock mass in the range $0.8-0.9 \mathrm{~mm} /$ year.
After crossing the Radochów zone, near the Kąty Bystrzyckie, the gradual slowdown of lift movements is noticeable, to approximately $0.2 \mathrm{~mm}$ /year (Stronie Śląskie vicinity). Uplift movements in this part of the Śnieżnik Massif had been previously assumed. They are partly confirmed by the presence of river gravel covered by basalts in Lądek Zdrój (Birkenmajer et al., 2002). Currently, gravels are located approximately $50 \mathrm{~m}$ above the level of the Biała Lądecka River (Birkenmajer et al., 2002; Badura et al., 2004). In the area of Chwalisław and Złoty Stok on the levelling line Złoty Stok-Stronie Śląskie, changes are at the level of -0.1 to $-0.3 \mathrm{~mm} /$ year (Fig. 8). Towards Orłowiec, subsidence trends deepen to about $-1.2 \mathrm{~mm} /$ year, and the amplitude of the changes reaches $-22.0 \mathrm{~mm}$. The results are contrary to the results of geomorphological and hydrographic observations (Krzyszkowski et al., 2000; Badura et al., 2004, 2007; Štěpančíková et al., 2008, 2010).

\section{CONCLUSIONS}

The analysis of vertical tectonic movements were carried out in the area, which in the Cenozoic, was one of the most tectonically modified in the NE part of the Bohemian Massif. The estimated amplitude of vertical crustal movement between Sudetes and the Fore-Sudetic block may exceed 1000 m (Badura et al., 


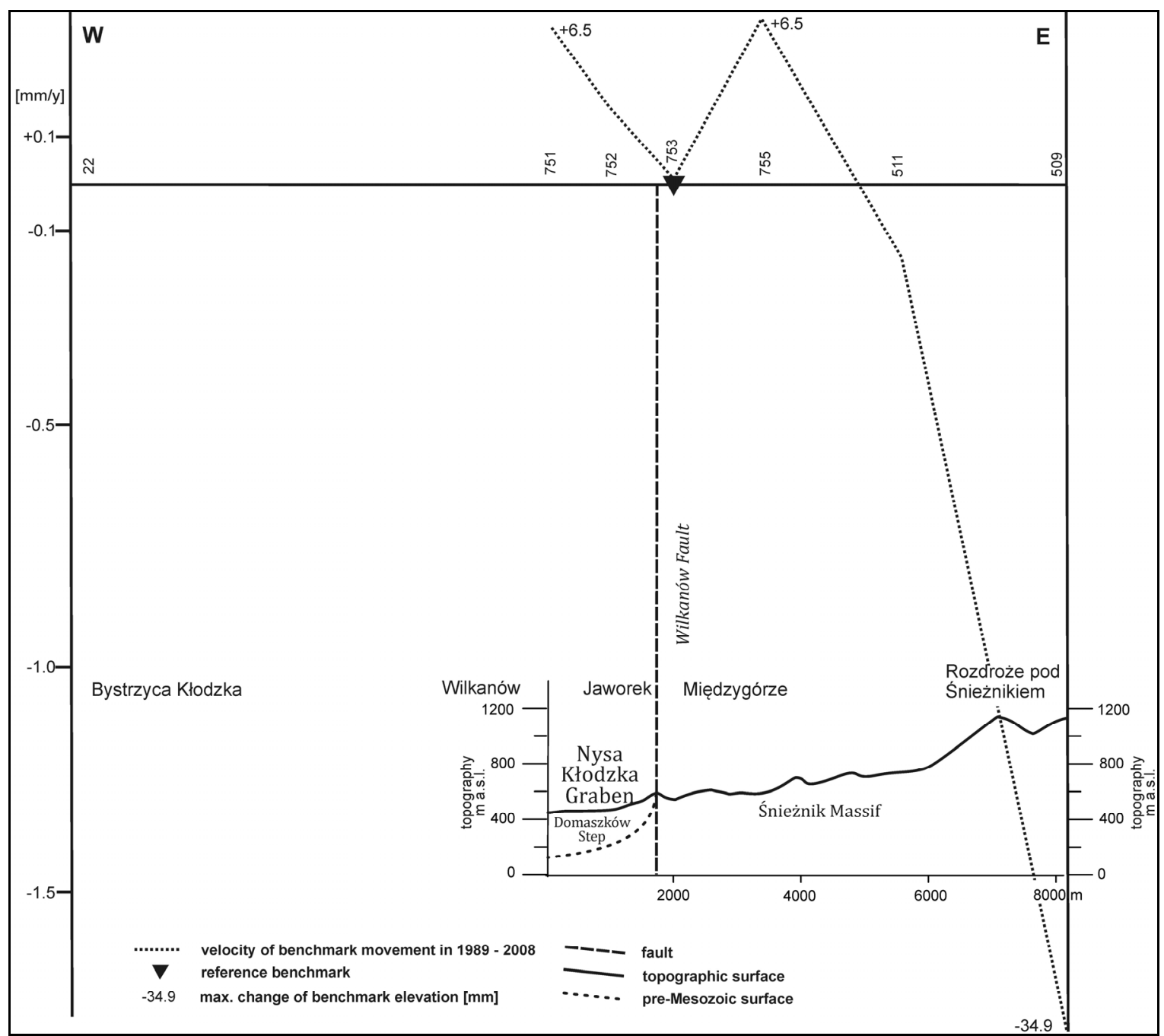

Fig. 6 Velocity of vertical displacements in the lines Bystrzyca Kłodzka-Jaworek and Jaworek-Stronie Śląskie (class II levelling).

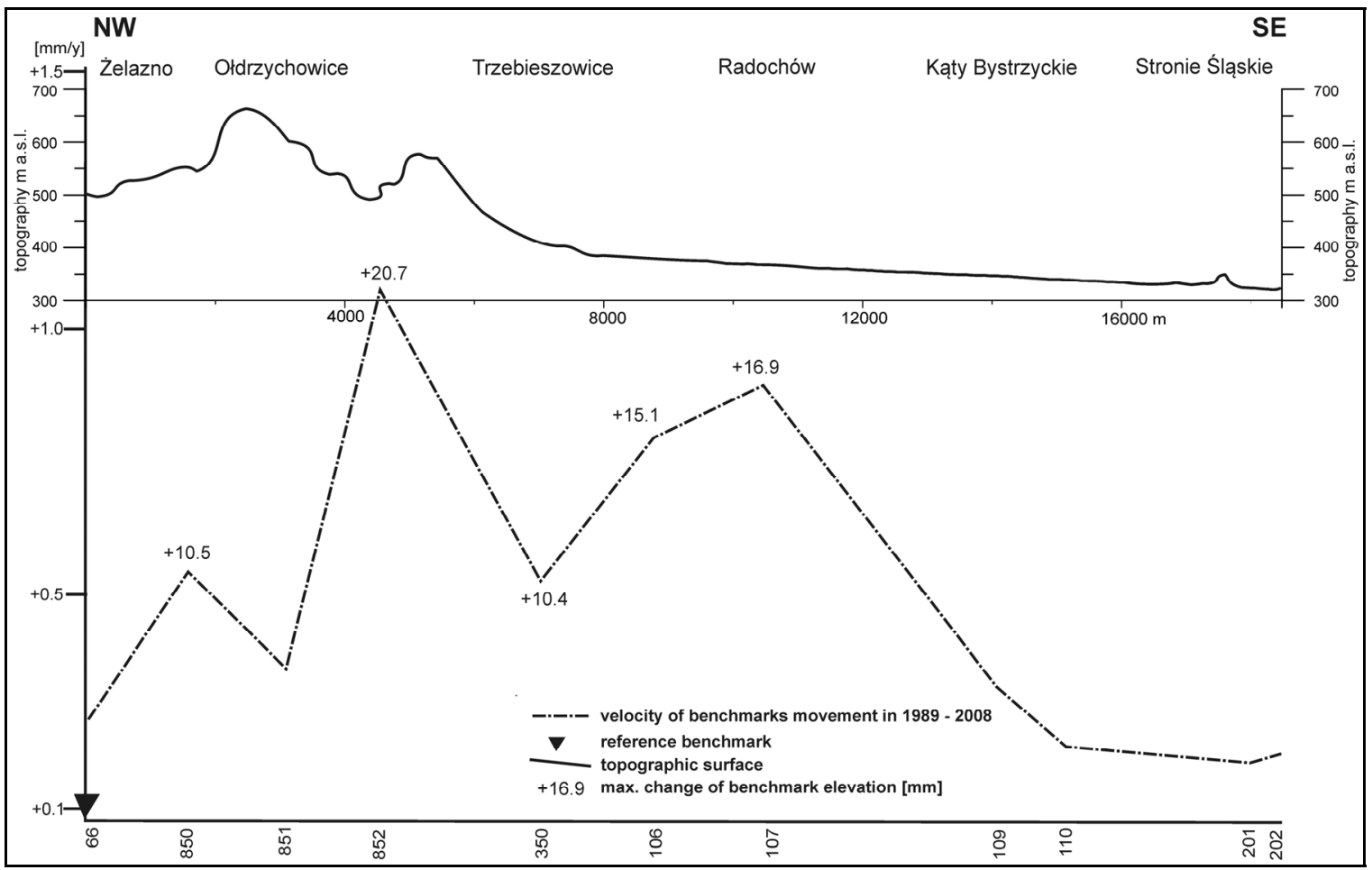

Fig. 7 Velocity of vertical displacements in the line Żelazno-Stronie Śląskie (class II levelling). 


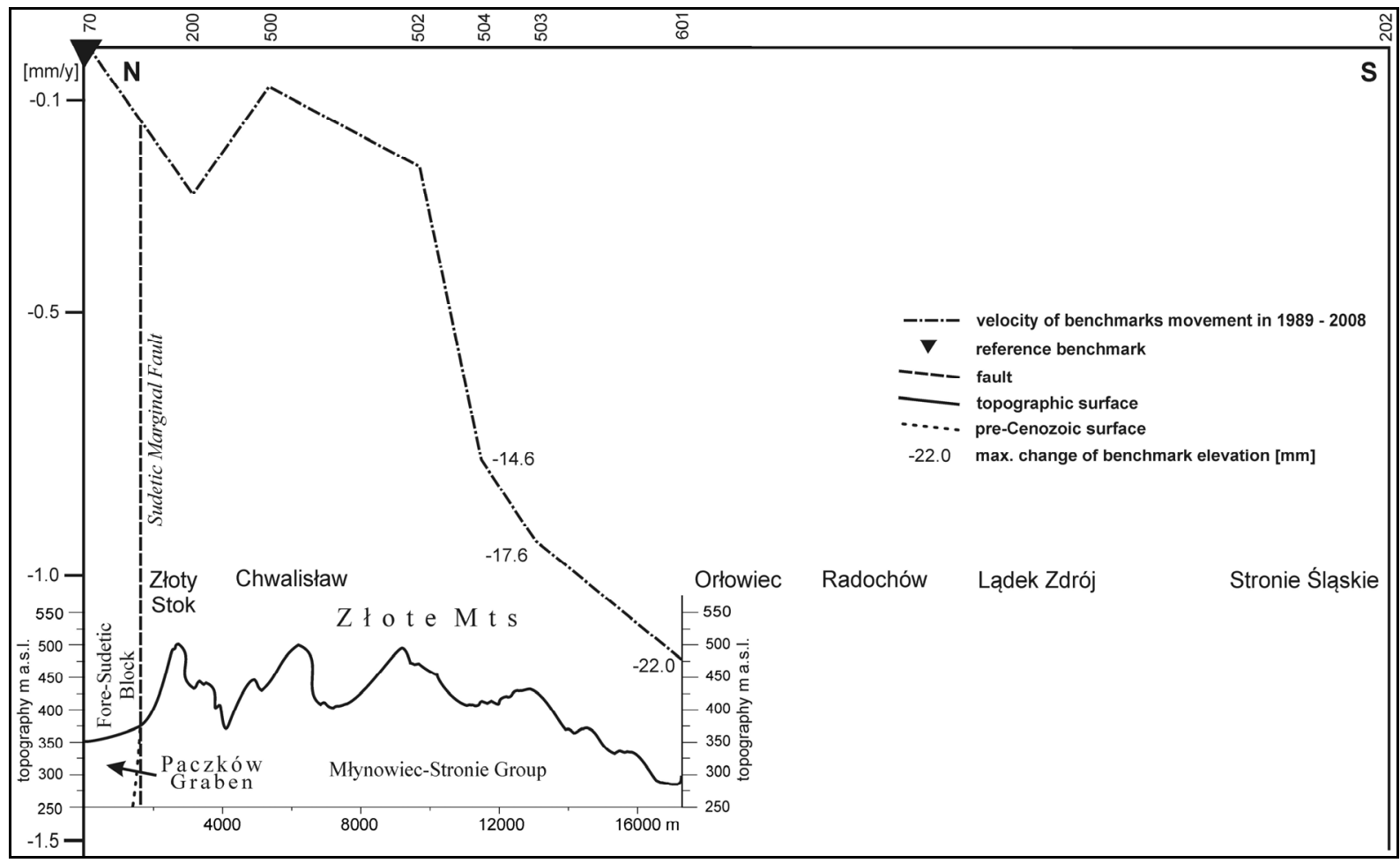

Fig. 8 Velocity of vertical displacements in the line Złoty Stok-Stronie Śląskie (class II levelling).

2007). In the Upper Nysa Kłodzka Graben, maximum height differences between the sub-Cretaceous surface and the present uppermost planation surfaces in the summit area exceed 1200 meters (Valečka, 1988; Don, 1996; Badura and Rauch, 2014). On this basis, we can assume that a similar order of movements occurred after the Cretaceous inversion, which included the Bohemian Massif. On the basis of geological and geomorphological evidence, the authors expected to obtain confirmation of the trend (but not the size of displacements), where vertical crustal movements have continued to the present day (Zeuner, 1928; Schwarzbach, 1942; Oberc and Dyjor, 1969; Radwański, 1975; Batik et al., 1996; Ivan, 1996; Don, 1996; Žatecká, 1996; Przybylski, 1998; Sroka and Kowalska, 1998; Krzyszkowski et al., 2000; Ranoszek, 2001; Badura et al., 2004, 2007; Kontny, 2004; Štěpančíková et al., 2008; Badura and Rauch, 2014). The results rather suggest that in the eastern part of the Central Sudetes subsidence prevails, which is consistent with the recent crustal movement models developed by Kowalczyk et al. (2010). This may indicate that after the glaciation of the Oder (Saale, Drenthe), and after the small lifting edge of the Sudetes by a few meters (Krzyszkowski et al., 2000), the Central European area decreases. In view of the divergent results between the geological and geomorphological data and geodetic measurements, there is a need to check areas of the Bohemian Massif by the method used in the investigations.

\section{ACKNOWLEDGMENTS}

This work was supported by Ministry of Science and Higher Education, Project NN 526223335 "Geodetic monitoring of the Waliszów-Morawa tectonic zone recent activity".

\section{REFERENCES}

Badura, J., Przybylski, B., Tokarski, A. and Świerczewska, A.: 2007a, Terraces od Nysa Kłodzka river and smallscale tectonic structures close to the Sudetic Marginal Fault at Janowiec (Bardo Mts.). Polish Geological Review, 55, 3, 228-235, (in Polish with English sum.).

Badura, J., Przybylski, B. and Zuchiewicz,W.: 2004, Cainozoic evolution of Lower Silesia, SW Poland: A new interpretation in the light of sub-Cainozoic and sub-Quaternary topography. Acta Geodyn. Geomater., 1, 3 (135), 7-29.

Badura, J. and Rauch, M.: 2014, Tectonics of the Upper Nysa Kłodzka Graben, Sudetes. Geologia Sudetica, 42, 137-148.

Badura, J., Zuchiewicz, W., Štěpančiková, P., Przybylski, B., Kontny, B. and Cacoń, S.: 2007b, The Sudetic Marginal Fault: a young morphotectonic feature of Central Europe. Acta Geodyn.Geomater., 4, 4 (148), 7-29.

Batik, P., Doktór, S., Graniczny, M. and Šebesta, J.: 1996, The role of discontinuous tectonic in the Śnieżnik Massif relief development. In: Jahn, A., Kozłowski, S. and Pulina, M. (Eds.), Śnieżnik Massif - Changes in the environment. Polish Ecological Agency Publ., 2733, (in Polish with English sum).

Birkenmajer, K., Pécskay, Z., Grabowski, J., Lorenc, M.W. and Zagożdżon, P.P.: 2002, Radiometric dating of the 
Tertiary volcanics in Lower Silesia, Poland. II. K-Ar and palaeomagnetic data from Neogene basanites near Lądek Zdrój, Sudetes Mts. Annales Societatis Geologorum Poloniae, 72, 119-129.

Cymerman, Z.: 2004, Tectonic map of the Sudetes and ForeSudetic Block 1:200 000. PIG Warsaw.

Don, J.: 1996, The Late Cretaceous Nysa Graben: implications for Mesozoic-Cenozoic fault-block tectonics of the Sudetes. Zeitschrift für geologische Wissenschaften, 24, 317-324.

Grygar, R. and Jelínek, J.: 2003, The Upper Morava and Nysa pull-apart Grabens - the neotectonic dextral transtension on the Sudetic Faults System. Acta Montana, Ser. A, 24, 51-59.

Ivan, A.: 1996, Morphotectonics of SE (margin of the Bohemian Cretaceous Basin, two half-grabens and their surroundings north of Brno (Moravia). Moravian Geographical Reports, 4, 1, 2-28.

Kapłon, J., Kontny, B., Grzempowski, P., Schenk, V., Schenková, Z., Balek, J. and Holešovský, J.: 2014, GEOSUD/SUDETEN network GPS data reprocessing and horizontal site velocity estimation. Acta Geodyn. Geomater., 11, 1 (173), 65-75.

DOI: 10.13168/AGG.2013.0058

Kontny, B.: 2004, Is the Sudetic Marginal Fault still active? Results of the GPS monitoring 1996 - 2002. Acta Geodyn. Geomater. 1, 3(135), 35-39.

Kowalczyk, K.: 2009, The levelling data in study of vertical movements of the Earth's crust on area of Poland. Acta Sci. Pol., Geodesia et Descriptio Terrarum, 8, 1, Wrocław, 31-43, (in Polish with English sum.).

Kowalczyk, K., Rapiński, J. and Mróz, M.: 2010, Analysis of vertical movements modelling through various interpolation techniques. Acta Geodyn. Geomater., 7, 4(160), 399-409.

Kowalczyk, K., Bednarczyk, M. and Kowalczyk, A.: 2011, Relational database of four precise levelling campaigns in Poland. 8th International Conference „Environmental Engineering”, Book Editors, Cygas, D.; Froehner, KD., 03/01, 1356-1361.

Krzyszkowski, D., Przybylski, B. and Badura, J.: 2000, The role of neotectonics and glaciation on terrace formation along the Nysa Kłodzka River in the Sudeten Mountains (southwestern Poland). Geomorphology, 33, 149-166.

Mazur, S., Aleksandrowski, P. and Szczepański, J.: 2005 , The presumed Teplá -Barrandian/Moldanubian terrane boundary in the Orlica Mountains (Sudetes, Bohemian Massif): structural and petrological characteristics. Lithos 82, 85-112. DOI: 10.1016/j.lithos.2004.12.008

Oberc, J. and Dyjor, S.: 1969, Sudetic Marginal Fault. Biul. Inst. Geol., 236, 124-142, (in Polish with English sum.).

Pospíšil, L., Švábenský, O. and Weigel, J.: 2013, Movement tendencies in the Moravia region: kinematical model. Acta Geodyn. Geomater., 10, 3 (171), 307-321. DOI: 10.13168/AGG.2013.0030

Przybylski, B.: 1998, Glacial and neotectonic constraints on the Quaternary evolution of the Fore-Sudetic reach of the Nysa Kłodzka River. Geol. Quarter., 42, 221-238.

Radwański, S.: 1975, Upper Cretaceous of the central part of the Sudetes in the light of new borehole materials. Biul. Inst. Geol., 187, 5-59, (in Polish with English sum.).
Ranoszek, W.: 2001, Tectonically-controlled morphological escarpments in the Sudetes in the light of numerical parameters. Unpublished Ph.D. thesis, Faculty of Natural Sciences, University of Wrocław, Wrocław, 200 pp., (in Polish).

Roštínský, P., Pospíšil, L. and Švábenský, O.: 2013, Recent geodynamic and geomorphological analyses of the Diendorf-Čebín Tectonic Zone, Czech Republic, Tectonophysics, 599, 45-66.

DOI: 10.1016-j.tecto.2013.04

Schwarzbach, M.: 1942, Das Diluvium Schlesiens. Neues Jb. Miner., 86, 189-246.

Špaček, P., Sýkorová, J., Pazdírková, J., Švancara, J. and Havír, J.: 2006, Present-day seismicity of the southeastern Elbe Fault System (NE Bohemian Massif). Stud. Geophys. Geod., 50, 233-258. DOI:10.1007/s11200-006-0014-z

Sroka, W. and Kowalska, A.: 1998, The preglacial fluvial deposits in the southern part of the Upper Nysa Depression, central Sudetes Mts., south western Poland. Geologia Sudetica, 31, 157-170.

Stackebrandt, W. and Franzke, H.J.: 1989, Alpidic reactivation of the Variscan consolidated lithosphere; the activity of some fracture zones in Central Europe. Zeitschrift fuer Geologische Wissenschaften, 17, 699712.

Štěpančíková, P., Hók, J., Nývlt, D., Dohnal, J., Sýkorová, I. and Stemberk, J.: 2010, Active tectonics research using trenching technique on the south-eastern setion of the Sudetic Marginal Fault (NE Bohemian Massif, central Europe). Tectonophysics, 485, 1, 269-282. DOI: $10.1016 /$ j.tecto.2010.01.004

Štěpančíková, P., Stemberk, J., Vilímek, V. and Košták, B.: 2008, Neotectonic development of drainage networks in the East Sudeten Mountains and monitoring of recent fault displacements (Czech Republic). Geomorphology, 102, 68-80.

DOI: 10.1016/j.geomorph.2007.06.016

Valečka, J.: 1988, Sedimentology of the Upper Cretaceous in the Králíky Graben (NE Bohemia). Sborník geol. věd, 43, 147-191, (in Czech with English sum.).

Wyrzykowski, T.: 1985, The map of the contemporary vertical movement velocities of the Earth's crust surface on the area of Poland. Institute of Geodesy and Cartography, Warsaw (in Polish).

Wyrzykowski, T.: 1988, Monography of Polish precise class I levelling networks. Institute of Geodesy and Cartography, Warsaw, (in Polish).

Žatečka, P.: 1996, The development of the river system in the upper basin of the Tichá Orlice. Sborník vlastivědných prací Orlické hory a Podorlicko, 8, 1724, (in Czech).

Żelaźniewicz, A., Jastrzębski, M., Redlińska-Marczyńska, A. and Szczepański, J.: 2014, The Orlica-Śnieżnik Dome, the Sudetes, in 2002 and 12 years later. Geologia Sudetica, 42, 105-123.

Zeuner, F.: 1928, Diluvialstatigraphie und Diluvialtektonik im Gebiet der Glatzer Neise. Jb. Schles. Ges. Vaterl. Kult., 110, 112-113.

Ziegler, P.A. and Dézes, P.: 2007, Cenozoic uplift of Variscan Massifs in the Alpine foreland: timing and controlling mechanisms. Global and Planetary Change, 58, 237-269.

DOI: $10.1016 /$ j.gloplacha.2006.12.004 